\title{
Metformin Inhibits Growth of Breast Cancer Cell T47D through Decreasing Expression of Protein p53, BCL2 and Cyclin D1
}

\author{
Irma Yanti Rangkuti ${ }^{1}$, Poppy Anjelisa Zaitun Hasibuan ${ }^{2}$, Tri Widyawati ${ }^{3}$, \\ Yahwardiah Siregar ${ }^{4}$
}

\begin{abstract}
${ }^{1}$ Department of Pharmacology, Faculty of Medicine, Universitas Islam Sumatera Utara, Medan, Indonesia, ${ }^{2}$ Department of Pharmacology, Faculty of Pharmacy, Universitas Sumatera Utara, Medan, Indonesia, ${ }^{3}$ Department of Pharmacology, Faculty of Medicine, Universitas Sumatera Utara, Medan, Indonesia, ${ }^{4}$ Department of Biochemistry, Faculty of Medicine, Universitas Sumatera Utara, Medan, Indonesia

Address for Correspondence: Irma YantiRangkuti, Department of Pharmacology, Faculty of Medicine, Universitas Islam Sumatera Utara, Medan, Indonesia. E-mail: irmayanti.rangkuti@fk.uisu.ac.id
\end{abstract}

\section{Abstract}

Background: Breast cancer is a disease that afflicts women only $0.5-1 \%$ are male breast cancers. Breast cancer has several variants and requires a different therapeutic approach, and until now, the therapy has not been satisfactory due to the emergence of resistance. Metformin is known to have a cytotoxic effect for breast cancer. Aims: This study aimed to analyze the metformin cytotoxic mechanisms covering the cell cycle, apoptosis, and expression of p53, bcl-2, and cyclin D1 T47D cells which exposed to metformin $\mathrm{HCl}$. Method: The study was conducted in vitro on T47D breast cancer cells which exposed to metformin concentrations of $1738.2 \mu \mathrm{g} / \mathrm{mL}$ and $3476.4 \mu \mathrm{g} / \mathrm{mL}$ and doxorubicin concentrations of $0.1 \mu \mathrm{g} / \mathrm{mL}$ and $0.2 \mathrm{\mu g} / \mathrm{mL}$ for $24 \mathrm{~h}$. Cell cycle testing and apoptosis using the flowcytometry method and expression test of p53 protein, bcl-2 and cycline D1 in T47D cells with immunocytochemistry. Data were analyzed by one-way ANOVA with Bonferroni's advanced test. Result: The results showed that metformin inhibited the G0-G1 phase of the T47D cell cycle, triggered T47D cell apoptosis, and significantly reduced p53, bcl-2, and cyclin $D 1$ protein expression $(P<0.05)$. Conclusion: The conclusion of the study, metformin inhibits T47D cells through inhibition of the cell cycle G0-G1 phase, reducing protein expression p53, bcl-2, and cyclin D1.

Keywords: Apoptosis, bcl-2, Cell cycle, Cyclin D1, Cytotoxic, Metformin, P53, T47D cell

\section{Introduction}

Cancer is one of the serious world health problems, and in 2008, there were 12.7 million new cancer cases and 7.6 million died of cancer. The most diagnosed cancers worldwide are lung cancer (1.6 million, 12.7\%), breast cancer (1.38 million, $10.9 \%)$, and colorectal cancer (1.23 million, 9.7\%). ${ }^{[1]}$ The 2012 Globocan statistics showed that around 1.7 million women were diagnosed with breast cancer with a mortality rate of around 522 thousand. ${ }^{[2]}$ Clinical breast cancer is classified according to morphological characteristics including infiltrating ductal carcinoma, infiltrating lobular carcinoma, tubular, mucinous, medullary, and adenoid cystic carcinoma. Classification based on the expression of estrogen receptors and progesterone and Her2 oncogene. ${ }^{[2]}$

The types of breast cancer are diverse according to various therapeutic approaches. It reported that many kinds of therapy have been carried out so far; some of them had problems including therapeutic effectiveness that varies among individuals or chemotherapy resistance made new problems. ${ }^{[3]}$ This study focused on the metformin, 1 , 1-dimetylbiguanide is derived from galegine alkaloid or isoamyl guanidine, the active substance of Gallega officinalis, also known as Goat's Rue. It has been used since 1958 as a Type 2 diabetes mellitus (DM)

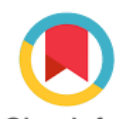

Check for updates
-) MR
How to cite this article: Rangkuti IY,

Hasibuan PAZ,

Widyawati T, Siregar Y. Metformin Inhibits Growth of Breast Cancer Cell T47D through Decreasing Expression of Protein p53, BCL2 and Cyclin D1. Journal of Medical Research and Innovation. 2019;3(2):e000164.

DOI: 10.32892/jmri.164

Publication history: Received: 20-01-2019 Accepted: 04-04-2019 Published: 04-04-2019

Editor: Dr. Varshil Mehta

Copyright: Rangkuti IY, Hasibuan PAZ,

Widyawati $T$, Siregar $Y$, This is an open-access article distributed under the terms of the Creative Commons Attribution License CC-BY 4.0., which permits unrestricted use, distribution, and reproduction in any medium, provided the original author and sources are credited.

Funding: NIL

Conflicts of Interest: NIL

MK Medkrux 


\section{Rangkuti, et al.: Metformin and expression of P53, BCL2, and Cyclin D1}

drug in the United Kingdom and 1995 at the United States and recommended as the first-line therapy for all patients newly diagnosed with Type 2 DM by the 2014 American Diabetes Association. ${ }^{[4]}$ The previous studies showed a reduced risk of cancer in Type 2 DM patients using metformin compared to patients who did not use metformin such as insulin, sulfonylureas, sitagliptin, and pioglitazone..$^{[5,6]}$ In practice, metformin works by inhibiting complex I respiratory chains in mitochondria ${ }^{[5,7]}$ where the mitochondrial respiratory chain functions to produce adenosine triphosphate (ATP). ${ }^{[8]}$ Complex I barriers in the mitochondrial respiratory chain resulted in the decreased cell ATP concentrations and increased AMP, then stimulated AMP-kinase. ${ }^{[9]}$ Set the activated AMP-kinase would phosphorylate various substrates that played a role in cell life. ${ }^{[10]}$ It found that the research in in vitro has been done including among several types of cancer cells such as WiDr cells, ${ }^{[11]}$ Hep G-2 cells, ${ }^{[12]}$ MCF-7 cells, ${ }^{[9]}$ MDA-MB-231, ${ }^{[13]}$ and MDA-MB-435 all showing suppression effects of cancer cell growth. This study used T47D cancer cells, ductal type breast cancer cells that express p53 proteins that might be mutated (missense mutation) at residue 194 (in the zinc-binding domain, L2). ${ }^{[14]}$ p53, a protein encoded in the TP53 gene, a tumor suppressor gene (tumor suppressor gene) which acts to block cell changes into cancer cells through three inhibiting mechanisms, namely quiescence, induction of permanent cessation of cells (senescence) or spurring programmed cell death (apoptosis), and barriers to angiogenesis. ${ }^{[15]}$ Thus, p53 causes antiapoptotic effects that occur through its bond with bcl-2, a family of antiapoptotic protein from Bcl-2. Then, p53 activates the proapoptotic bcl-2 protein family; as a result, there is an increase in permeability of the mitochondrial membrane, cytochrome $\mathrm{C}$ is released, and finally, apoptosis occurs through activation of the caspase. ${ }^{[16]}$ The $\mathrm{p} 53$ also has an effect on the cell cycle, where $\mathrm{p} 53$ acts as a negative regulator protein and cyclin kinase groups Cyclin-dependent kinase (CDK) as a positive regulator of cell cycle. ${ }^{[16]}$

It found that p53 mutations in breast cancer cells contribute to tumor formation because it increases the breast cancer cell defense through the effects of cell apoptosis ${ }^{[14,17,18]}$ and also increases resistance to chemotherapy ${ }^{[17,18]}$ genomic instability, disruption of spindle checkpoint control, ${ }^{[17]}$ and mutant p53 protein that has shown to be activators a number of genes including $\mathrm{c}-\mathrm{Myc}$, topoisomerase I, and MDR-1. ${ }^{[19]}$
Early research conducted by Rangkuti et al., 2018, showed that metformin had a cytotoxic effect on T47D breast cancer cells with $\mathrm{IC}_{50} 1738.2 \mu \mathrm{g} / \mathrm{mL}$, much smaller than the control of doxorubicin with ${ } C_{50} 0.1 \mu \mathrm{g} / \mathrm{mL} .{ }^{[20]}$ The mechanism of the inhibition of T47D cell growth is due to exposure to metformin. It requires further investigation of the cells cycle and apoptosis along with the proteins that play a role in it.

\section{Materials and Methods}

\section{Cell line and reagent}

This research used the T47D breast cancer cell line which was provided by the Faculty of Medicine, Gadjah Mada University of Indonesia. Cells are cultured in RPMI 1640 media (Sigma, USA) with $10 \%$ fetal bovine serum (Thermo, Chile), under standard culture conditions $\left(37^{\circ} \mathrm{C}, 95 \%\right.$ humidified water, and $5 \% \mathrm{CO}_{2}$ ). Metformin was produced by PT. Metformin was produced by PT. Dexa Medica Palembang (Indonesia), but Oxoxorubicin was by PT. Ferron Parr Pharmaceuticals of Indonesia. This study used the anti-p-53 antibodies, anti-bcl-2, and anti-cyclin D1 (Sigma, America). The serial dilution solution of the sample is prepared immediately before the experiment was carried out.

\section{Cell cycle testing and apoptosis}

Apoptosis and T47D cell cycle testing were using the method of flow cytometry. The number of cells needed $5 \times 10^{5}$ cells/well on the 6 -well plate, incubated for $24 \mathrm{~h}$; the next day, the cell plus the metformin solution was reincubated for $24 \mathrm{~h}$. Then, the media of each well is inserted in each $15 \mathrm{~mL}$ cone tube, washed with phosphate-buffered saline (PBS) 1 time reenter the same cone. Added $250 \mu \mathrm{L}$ trypsin to each well and then incubated for $3 \mathrm{~min}$. After that, plus $1 \mathrm{~mL}$ of culture media; then, the media was accommodated in the same cone tube. Centrifuging at a speed of $600 \mathrm{rpm}$ for $5 \mathrm{~min}$, the supernatant was discarded. Added $1 \mathrm{~mL}$ PBS, the media was transferred to a $1.5 \mathrm{~mL}$ microtube; it was centrifuged again at a speed of $2000 \mathrm{rpm}$ for 3 minutes, after which the supernatant was removed. Cell cycle testing and iodide propidium were done while apoptosis testing plus Annexin $\mathrm{V}$ and iodide propidium were made. Then, it was measured by means of the FACSCalibur (BectonDickinson) flowsitometer. ${ }^{[21]}$ The cell pellets were suspended in $50 \mu \mathrm{g} / \mathrm{ml}$ propidium iodide in the 


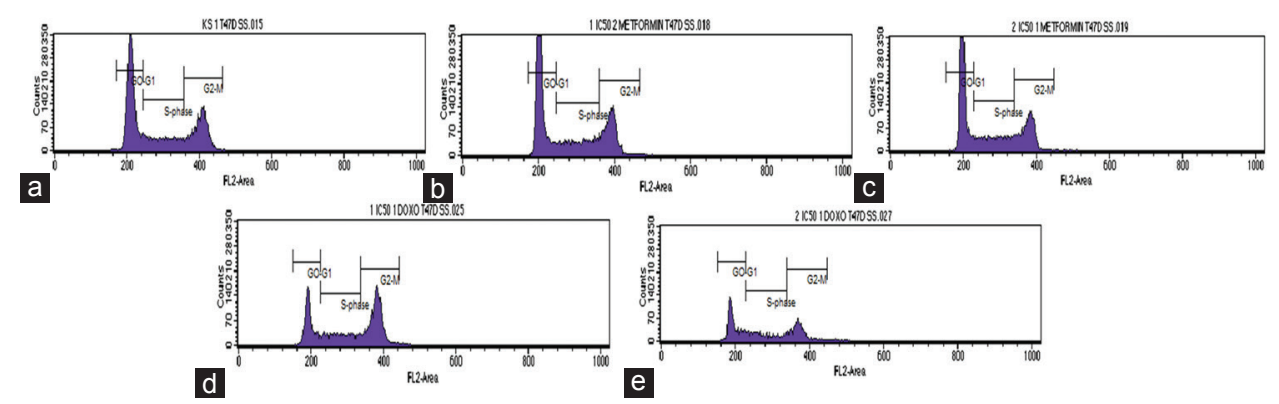

Figure 1: T47D cell cycle histogram in (a) control cell (b) exposure to metformin concentration of $1738.2 \mu \mathrm{G} / \mathrm{mL}$ (c) exposure to metformin concentration of $3476.4 \mu \mathrm{G} / \mathrm{mL}$ (d) exposure to doxorubicin concentration of $0.1 \mu \mathrm{G} / \mathrm{mL}$ (e) exposure to doxorubicin concentration of $0.2 \mu \mathrm{G} / \mathrm{mL}$

presence of $100 \mu \mathrm{g} / \mathrm{ml}$ RNase and Triton-X solution and incubated for $10 \mathrm{~min}$ at $37^{\circ} \mathrm{C}$ in the dark. Cell cycle distribution was analyzed using the flow cytometry, then analyzed with the Cell Quest program.

\section{Immunochemistry}

Analysis of protein expression of $\mathrm{p}-53, \mathrm{Bcl}-2$, and cyclin D1 was using T47D cells grown immunochemistry. Before T47D cell is being planted, first put each coverslip in a 24-well pitting plate. The cell planted at a density of $5 \times 10^{4}$ cells/wells, incubated for the last $24 \mathrm{~h}$, then the media discarded. Cell that being incubated then added with metformin test solution incubated back for $24 \mathrm{~h}$. After incubation, the metformin test solution and the culture media are removed, washed with PBS 1 time. Cells were fixed with cold methanol (Merck) for 10 minutes and discarded. After that, coverslip on each of the wells is removed and placed on a glass slide, washed with PBS 2 times, washed with distilled water, and then got dried; add the prediluted blocking serum at room temperature for 10 minutes, then discarded. After incubation, the monoclonal antibodies p-53/Bcl-2/ cyclin D1 were added to the cells and then incubated for 1 hour at room temperature. Coverslip then washed with PBS and etched secondary antibody (Biotinylated universal secondary antibody) (Star Trek Universal HRP Detection Kit, Ref. STUHRP 700L10-KIT, Biocare Medical) and incubated for $10 \mathrm{~min}$. The cells washed again using PBS and etched with streptavidin enzyme horseradish peroxidase (HRP, Star Trek Universal Detection Kit, Ref. STUHRP 700L10-KIT, Biocare Medical) and incubated for 10 minutes. Cells were washed and then added 3,3'-diaminobenzidin (DAB) (Star Trek Universal HRP Detection Kit, Ref. STUHRP 700L10-KIT, Biocare Medical), incubation
Table 1: Percentage of accumulation in each phase in the T47D cell cycle

\begin{tabular}{|l|c|c|c|}
\hline Kinds of treatment & \multicolumn{3}{c}{ Cell cycle phase (\%) } \\
\cline { 2 - 5 } & G0-G1 & S & G2-M \\
\hline Control cell & 49.20 & 20.93 & 30.15 \\
\hline Metformin $1738.2 \mu \mathrm{g} / \mathrm{mL}$ & 52.99 & 22.03 & 25.36 \\
\hline Metformin $3476.4 \mu \mathrm{g} / \mathrm{Ml}$ & 54.48 & 22.07 & 23.79 \\
\hline Doxorubicin $0.1 \mu \mathrm{g} / \mathrm{mL}$ & 27.90 & 24.75 & 47.31 \\
\hline Doxorubicin $0.2 \mu \mathrm{g} / \mathrm{mL}$ & 39.97 & 28.22 & 31.34 \\
\hline
\end{tabular}

for 2 min (until the brown color). Cells were washed again with PBS and distilled water then with a solution Mayer-Hematoxylin (Dako) and incubated for 5 minutes, and then cells were washed again using distilled water to clean, add $70 \%$ ethanol incubation for $2 \mathrm{~min}$, wipe, then dropped into a solution of xylol and dry. After drying, coverslip placed on a glass slide and a few drops of mounting media and covered with a cover glass. Cells observation was performed using Olympus brand light microscope with $\times 400$.

\section{Results: Metformin Inhibits The G0-G1 Phase of the T47d Cell Cycle}

Previous research showed that the metformin has a cytotoxic effect against cancer cells T47D. To find its effect, then a test to determine the cell cycle bottleneck effect of metformin on cell cycle ${ }^{[20]}$ was administered. It was made by the exposure to metformin concentrations of $1738.2 \mathrm{mg} / \mathrm{mL}$ and $3476.4 \mathrm{~g} / \mathrm{mL}$ for $24 \mathrm{~h}^{[20]}$ which showed the accumulation of cells in G0-G1 phase, that is, dose dependent, whereas exposure to doxorubicin concentration of $0.1 \mathrm{mg} / \mathrm{mL}$ and $0.2 \mathrm{mg} / \mathrm{mL}$ for $24 \mathrm{~h}^{[20]}$ showed barriers $\mathrm{G} 0$ phase of the cell cycle at the G2-M-G1d [Figure 1 and Table 1]. 
Metformin decreases cyclin D1 protein expression in T47D breast cancer cell

Cell accumulation in the G0-G1 phase due to exposure to metformin is then required to trace the protein that plays a role, for that the cyclin D1 expression is examined G1.

Exposure to metformin concentrations of 1738.2 $\mu \mathrm{g} / \mathrm{mL}$ and $3476.4 \mu \mathrm{g} / \mathrm{mL}$ for $24 \mathrm{~h}^{[20]}$ to T47D cells showed a decrease in cyclin D1 expression compared to controls [Figures 2-4, Table 2].

Based on the ANOVA test obtained $P=0.014$ $(P<0.05)$, there were significant differences in the expression of cyclin D1 in all three groups. The results show a significant difference in the expression of cyclin D1 in the cell group which was exposed to metformin $3476.4 \mu \mathrm{g} / \mathrm{mL}$ ( $4.40 \pm 3.89 \%)$ with control cells $(14.61 \pm 2.49 \%)$ with $P<0.05$.

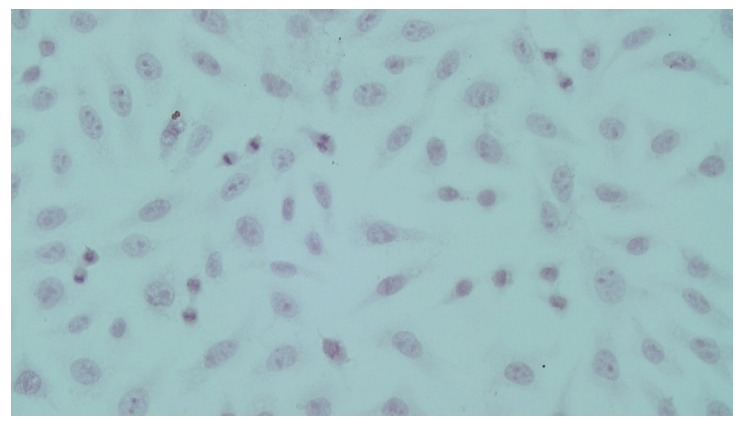

Figure 2: The expression of cyclin D1 in control cells T47D

Description: The black arrow indicates cells expressing cyclin D1.

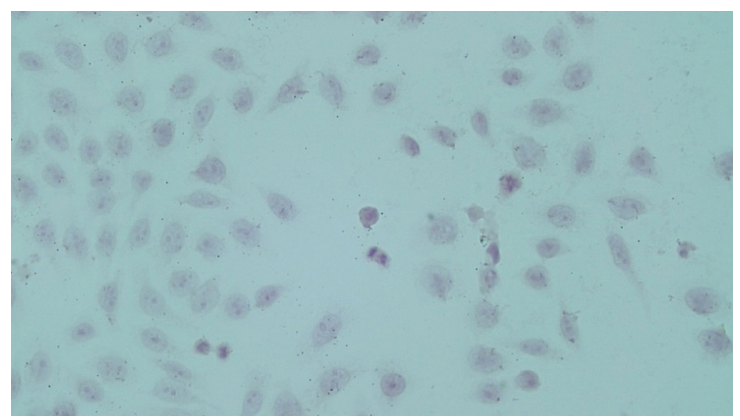

Figure 3: The expression of cyclin D1 in control cells T47D cells described metformin concentration of $1738.2 \mathrm{mG} / \mathrm{mL}$

Description: The black arrow indicates a cell that expresses cyclin D1.
Metformin has apoptotic ability for T47D breast cancer cells

The results of apoptotic testing showed that the ability of apoptosis metformin was smaller than doxorubicin [Figure 5 and Table 3].

Metformin decreases P53 protein expression T47D breast cancer cells

In this step, p53 protein expression testing was performed on control cell T47D cells, T47D cells were exposed to metformin $1738.2 \mu \mathrm{g} / \mathrm{mL}$ and $3476.4 \mu \mathrm{g} / \mathrm{mL}$ for $24 \mathrm{~h}$, and T47D cells were exposed to doxorubicin $0.1 \mu \mathrm{g} / \mathrm{mL}$ and $0.2 \mu \mathrm{g} / \mathrm{mL}$ for $24 \mathrm{~h}$. The expression of $\mathrm{p} 53$ protein in cells exposed to doxorubicin $0.2 \mu \mathrm{g} / \mathrm{mL}$ is difficult to assess due to lysis cells.

Cells that positively express p53 visually appear to have a brown/dark cytoplasm, whereas cells that do not express p53 are bluish transparent. ${ }^{[22]}$

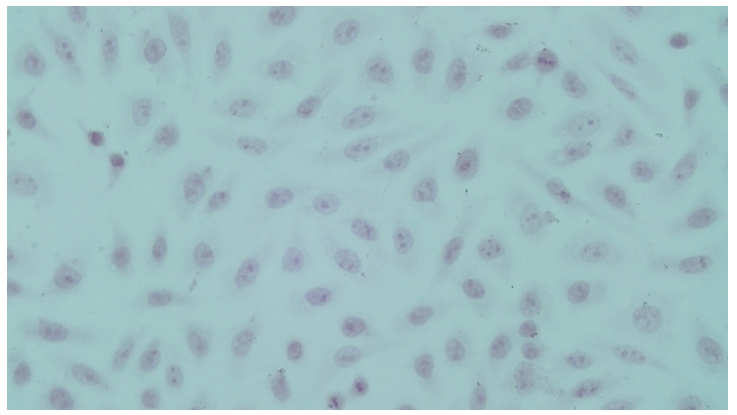

Figure 4: Cyclin expression D1 in T47D cell described metformin concentration of $3476.4 \mathrm{mG} / \mathrm{mL}$

Description: The black arrow indicates a cell that expresses cyclin D1.

Table 2: Analysis of cyclin D1 protein expression in T47D cancer cell using ANOVA test

\begin{tabular}{|l|l|c|c|} 
No. & Treatment & \multicolumn{1}{c}{$\begin{array}{c}\text { Expression of } \\
\text { cyclin D1 in T47D } \\
\text { cells }\end{array}$} & P value \\
\hline 1. & Control cell & $14.61 \pm 2.49 \%$ & 0.014 \\
\hline 2. & $\begin{array}{l}\text { Metformin } \\
1738.2 \mu \mathrm{g} / \mathrm{mL}\end{array}$ & $7.76 \pm 2.13 \%$ & \\
\hline 3. & $\begin{array}{l}\text { Metformin } \\
3476.4 \mu \mathrm{g} / \mathrm{mL}\end{array}$ & $4.40 \pm 3.89 \% *$ & \\
\hline
\end{tabular}

Description: Data were analyzed by one-way ANOVA with Bonferroni's advanced test, ${ }^{*} P<0.05$ versus control 


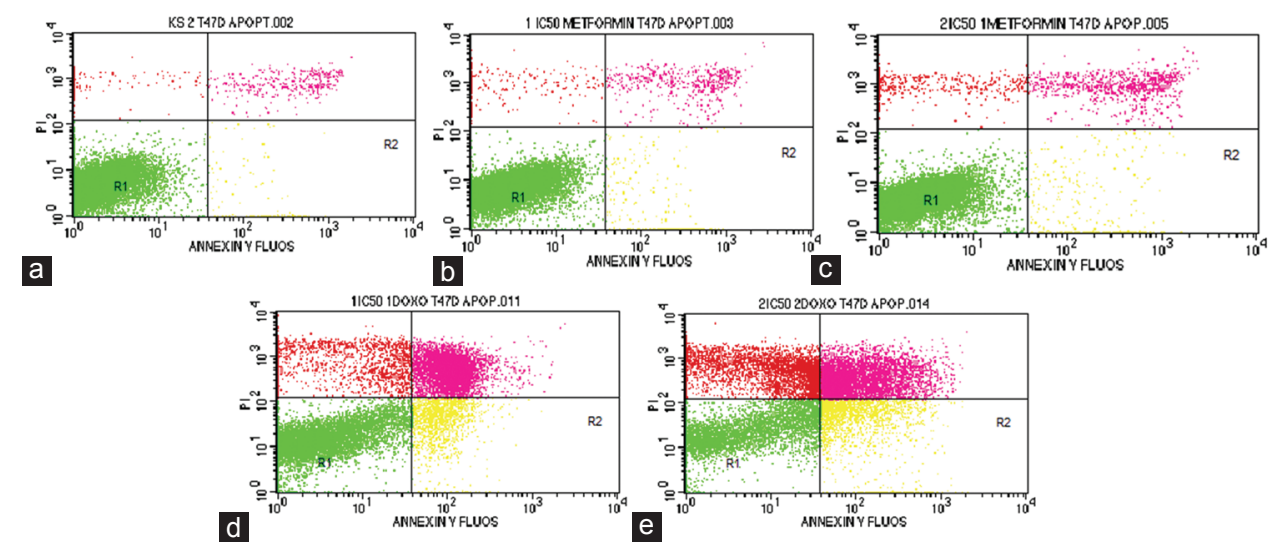

Figure 5: T47D cell apoptosis test in (a) control cells (b) exposure to metformin concentration of $1738.2 \mu \mathrm{G} / \mathrm{mL}$ (c) exposure to metformin concentration of $3476.4 \mu \mathrm{G} / \mathrm{mL}$ (d) exposure to doxorubicin concentration of $0.1 \mu \mathrm{G} / \mathrm{mL}$ (e) exposure to doxorubicin concentration of $0.2 \mu \mathrm{G} / \mathrm{mL}$ Description: R1=Living cell; R2=cells undergo initial apoptosis; R3=cells undergo final apoptosis; R4=Cells undergo necrosis.

Table 3: Results of T47D cell apoptosis tests

\begin{tabular}{|l|c|c|c|c|}
\hline Treatment & R1 (\%) & R2 (\%) & R3 (\%) & 1.73 \\
\hline Control cell & 96.45 & 0.64 & 2.44 & 1.20 \\
\hline Metformin $1738.2 \mu \mathrm{g} / \mathrm{mL}$ & 94.67 & 1.28 & 3.92 & 2.90 \\
\hline Metformin $3476.4 \mu \mathrm{g} / \mathrm{mL}$ & 91.31 & 1.86 & 28.41 & 10.14 \\
\hline Doxorubicin $0.1 \mu \mathrm{g} / \mathrm{mL}$ & 53.61 & 7.99 & 31.25 & 26.20 \\
\hline Doxorubicin $0.2 \mu \mathrm{g} / \mathrm{mL}$ & 31.71 & 11.19 & \\
\hline
\end{tabular}

Description: R1=Living cell; R2=Cells undergo initial apoptosis; R3=Cells undergo final apoptosis; R4=Cells undergo necrosis

Based on the ANOVA test obtained $P=0.028(P<0.05)$, there were significant differences in the expression of p53 in the Figures 6-9. The results according to Table 4 show a significant difference in the expression of p53 in the cell group which was exposed to metformin $3476.4 \mu \mathrm{g} / \mathrm{mL}(6.98 \pm 2.74 \%)$ with the control cell group $(14.54 \pm 1.60 \%)$ with $P<0.05$.

\section{Metformin decreases BCL-2 T47D breast cancer protein expression}

Testing of bcl-2 expression was performed on T47D cell control cells, T47D cells which were exposed to metformin $1738.2 \mu \mathrm{g} / \mathrm{mL}$ and $3476.4 \mu \mathrm{g} / \mathrm{mL}$ for $24 \mathrm{~h}$ and T47D cells exposed to doxorubicin $0.1 \mu \mathrm{g} / \mathrm{mL}$ and $0.2 \mu \mathrm{g} / \mathrm{mL}$ for $24 \mathrm{~h}$. Expression of bcl-2 in cells exposed to doxorubicin $0.2 \mu \mathrm{g} / \mathrm{mL}$ is difficult to assess due to lysis cells.

Visually positive cells expressing bcl-2 appear to have a brown/dark cytoplasm, while cells that do not express bcl-2 are colored bluish transparent.
Based on the ANOVA test, it obtained $P=0.000$ $(P<0.05)$, there were significant differences in the expression of bcl-2 in the Figures 10-13. The corresponding results in Table 5 show a significant difference in the expression of bcl-2 in the cell group exposed to metformin $1738.2 \mu \mathrm{g} / \mathrm{mL}(5.46 \pm 1.19 \%)$ and doxorubicin $0.1 \mu \mathrm{g} / \mathrm{mL}(7.4 \pm 2.00 \%)$ with the control cell group $(14.54 \pm 1.60 \%)$ with p value $<0.01$, and in the metformin group, $3476.4 \mu \mathrm{g} / \mathrm{mL}(2.84 \pm$ $1.16 \%)$ significantly different from the control cell $(14.54 \pm 1.60 \%)$ with a value of $P<0.001$.

\section{Discussion}

It was found that in the previous studies showed that metformin had cytotoxic activity against T47D cells with $\mathrm{IC}_{50} 1738.1875 \pm 141.63 \mu \mathrm{g} / \mathrm{mL}$. ${ }^{[20]}$ The toxicity of metformin to cells T47D was based on the mechanism of metformin inhibiting complex I respiratory, chains in mitochondria. It ended up stimulating various substrates which caused various effects in the form of activation of glycolysis. Thus, 
Table 4: Analysis of P53 protein expression in T47D cancer cells using ANOVA test

\begin{tabular}{|l|l|c|c|}
\hline No & Treatment & \multicolumn{3}{c|}{$\begin{array}{c}\text { Expression of } \\
\text { p53 to T47D } \\
\text { cell (mean } \pm \text { SD \%) }\end{array}$} \\
\hline 1. & Control cell & $14.54 \pm 1.60$ & 0.028 \\
\hline 2. & $\begin{array}{l}\text { Metformin } \\
1738.2 \mu \mathrm{g} / \mathrm{mL}\end{array}$ & $11.69 \pm 3.28$ & \\
\hline 3. & $\begin{array}{l}\text { Metformin } \\
3476.4 \mu \mathrm{g} / \mathrm{mL}\end{array}$ & $6.98 \pm 2.74^{*}$ & \\
\hline 4. & $\begin{array}{l}\text { Doxorubicin } \\
0.1 \mu \mathrm{mL}\end{array}$ & $12.33 \pm 1.59$ & \\
\hline
\end{tabular}

Description: Data were analyzed by one-way ANOVA with Bonferroni's advanced test, ${ }^{*} P<0.05$ versus control

Table 5: Analysis of bcl-2 protein expression in T47D cells using ANOVA test

\begin{tabular}{|l|l|c|c|}
\hline \multicolumn{5}{|c|}{$\begin{array}{c}\text { Treatment } \\
\text { toT47D cell }\end{array}$} \\
\hline 1. & Control cell & $14.04 \pm 1.32 \%$ & 0.000 \\
\hline 2. & $\begin{array}{l}\text { Metformin } \\
1738.2 \mu \mathrm{g} / \mathrm{mL}\end{array}$ & $5.46 \pm 1.19 \% * *$ & \\
\hline 3. & $\begin{array}{l}\text { Metformin } \\
3476.4 \mu \mathrm{g} / \mathrm{mL}\end{array}$ & $2.84 \pm 1.16 \% * * *$ & \\
\hline 4. & $\begin{array}{l}\text { Doxorubicin } \\
0.1 \mu \mathrm{m} / \mathrm{mL}\end{array}$ & $7.4 \pm 2.00 \% * *$ & \\
\hline
\end{tabular}

Description: Data were analyzed by one-way ANOVA with Bonferroni's advanced test, ${ }^{*} P<0.05$ versus control, ${ }^{* *} P<0.01$ versus control, $* * * P<0.001$ versus control

the inhibition of anabolic pathways in inhibiting fatty acid synthesis, cholesterol, synthesis of ribosomal RNA, resistance to cycles cells through AMPK phosphorylation to $\mathrm{p}-53$ which causes an increase in transcription of $p-21$ a CDK inhibitor that plays a role in the cell cycle, and has an effect on the occurrence of apoptosis. ${ }^{[5,7,8,10]}$

The mechanism of cytotoxic metformin had been tested through the cell cycle and apoptosis. It was a cell cycle of proliferation process that mediated the growth and development of living things, had two main phases, namely the $S$ phase (synthesis) and the $\mathrm{M}$ phase (mitosis). Phase $\mathrm{S}$ was the phase of chromosomal DNA replication in cells while in Phase $M$, there is a separation of two sets of chromosomal DNA into two cells. ${ }^{[23]}$ In addition, there were phases that limit the two main phases called Gap: G1 (Gap-1) before the Phase S and after the $S$ phase is called G2 (Gap-2). In the G1 phase, the cell prepares for DNA synthesis. That phase was the

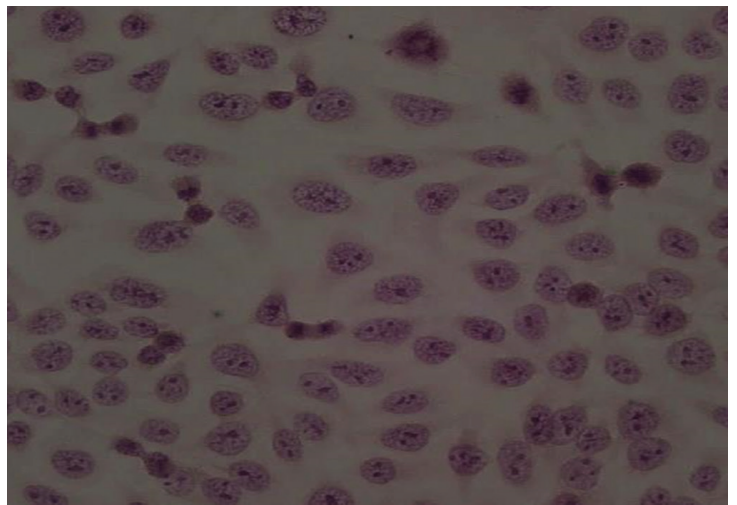

Figure 6: Expression of P53 proteins in T47D control cells

Description: Black arrows indicate cells expressing p53.

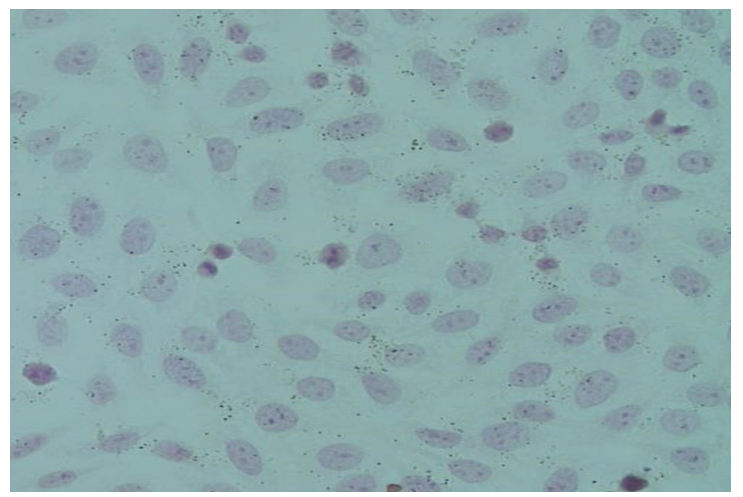

Figure 7: Expression of P53 in T47D cells exposed to metformin concentration of $1738.2 \mu \mathrm{G} / \mathrm{mL}$

Description: Black arrows indicate cells expressing p53.

initial phase of cell cycle progression regulated by extracellular factors such as mitogens and adhesion molecules. That phase marker was the expression and synthesis of protein as preparation for entering the $S$ phase. In the $G 2$ phase, the cell carried out further synthesis which sufficient for the cleavage process so that the cell was ready to do division in the M phase. ${ }^{[24]}$

This study displayed metformin, leading to cell cycle arrest in the G0-G1 phase, that was in accordance with the results of the $Q u$ and Cai study. ${ }^{[12,25]} \mathrm{G1}$ (Gap-1) is a cell preparation phase for DNA synthesis, and this phase would be exceeded if cell requirements such as nutrition, cell size, and growth factors have been fulfilled. Metformin working by inhibiting the 


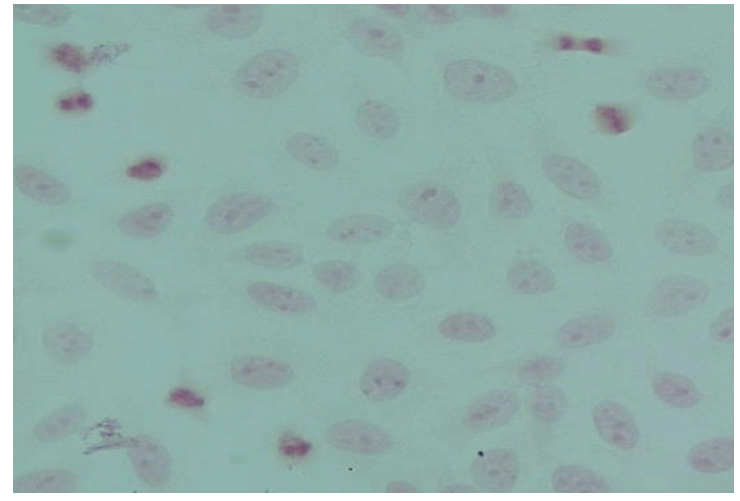

Figure 8: Expression of P53 in T47D cells exposed to metformin concentration of $3476.4 \mu \mathrm{G} / \mathrm{mL}$

Description: Black arrows indicate cells
expressing $\mathrm{p} 53$.

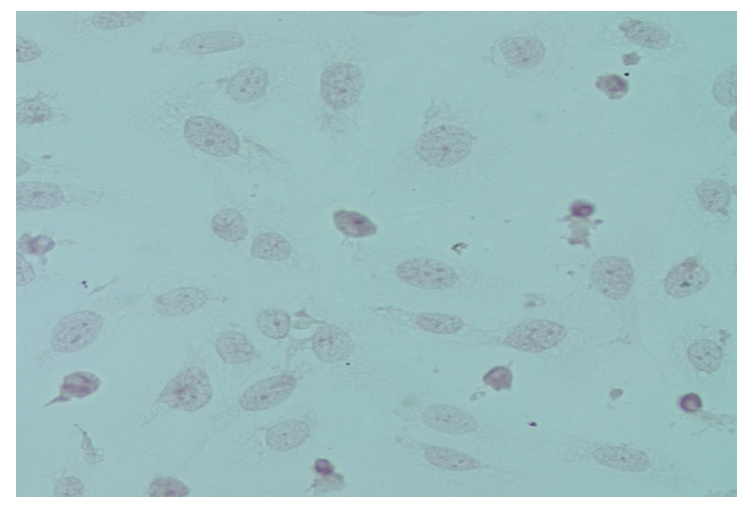

Figure 9: Expression of P53 in T47D cells exposed to doxorubicin concentration of $0.1 \mu \mathrm{G} / \mathrm{mL}$

Description: Black arrows indicate cells expressing $\mathrm{p} 53$.

mitochondrial respiratory chain I complex with the consequent inhibition of ATP formation resulting in AMPK activation which caused barriers to protein synthesis, lipids, and ribosomal RNA which were needed by cells to live and develop. ${ }^{[12,26]}$ It explained that the occurrence of cell growth barriers through cell cycle arrest in the G0-G1 phase. The extension of the G0-G1 phase also occurred in MCF-7 cells exposed to a concentration of $2.5,5,10$, and 20 $\mathrm{mM}$ and increasingly elongated in the next 2 and 3 days of metformin exposure. ${ }^{[9]}$ Different from doxorubicin which also works in the G2-M phase, cytotoxic activity of Doxorubicin through inhibition of topoisomerase II, DNA intercalation, membrane

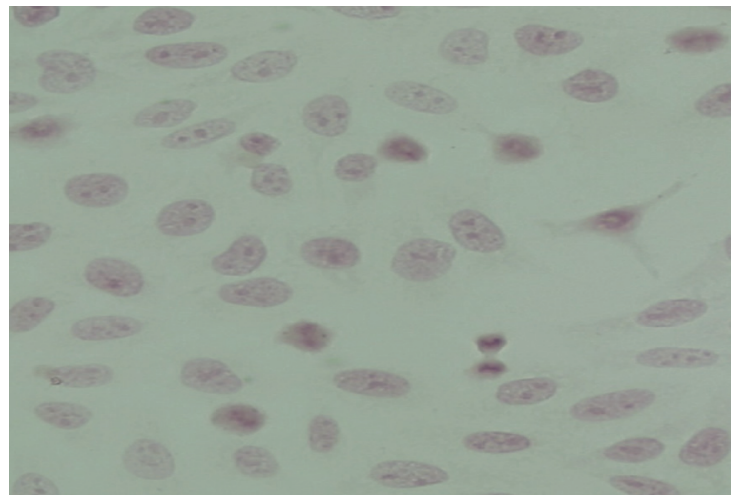

Figure 10: Expression of bcl-2 Proteins in T47D control cells

Description: Black arrows indicate cells expressing bcl-2.

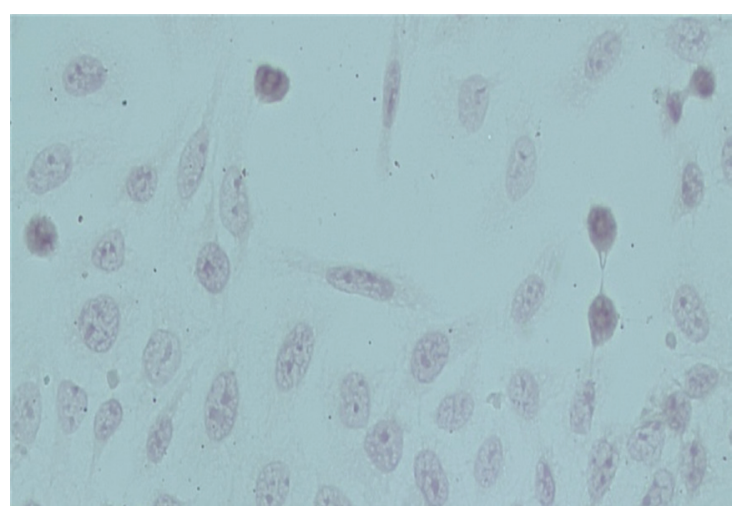

Figure 11: Expression of bcl-2 in T47D cells exposed to metformin concentration of $1738.2 \mu \mathrm{G} / \mathrm{mL}$

Description: Black arrows indicate cells expressing bcl-2.

cell binding and the formation of semiquinone free radicals and oxygen free radicals. ${ }^{[27]}$

Doxorubicin is one of the anthracycline antibreast cancer drugs currently used in combination regimens and for other types of cancer such as leukemia. ${ }^{[28]}$ Doxorubicin was used as a positive control in this study, because the drug was still used, and it showed an anti-cancer effect on T47D cells. ${ }^{[29]}$ Doxorubicin working specifically in the $S$ phase that was related to its mechanism of action to inhibit DNA and RNA synthesis, intercalation between base pairs and interact with topoisomerase II. ${ }^{[30]}$

Metformin exposure slightly increased T47D cell apoptosis compared to the effect of doxorubicin apoptosis. Previous metformin research on T47D 


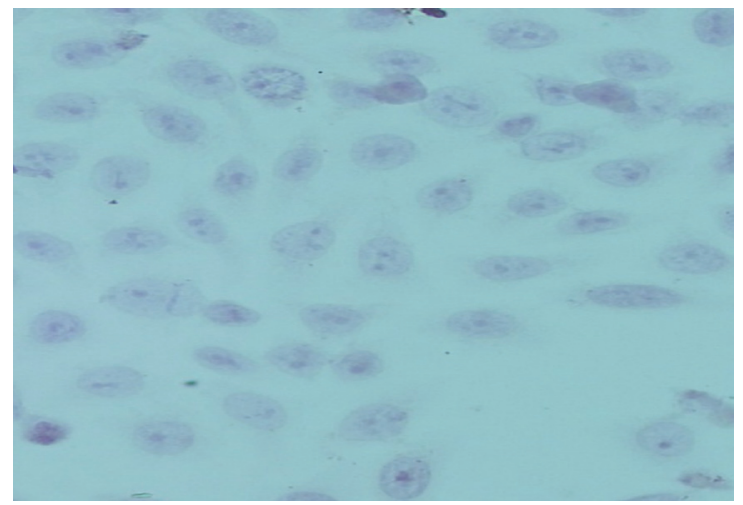

Figure 12: Expression of bcl-2 in T47D cells exposed to metformin concentration of $3476.4 \mu \mathrm{G} / \mathrm{mL}$

Description: Black arrows indicate cells expressing bcl-2.

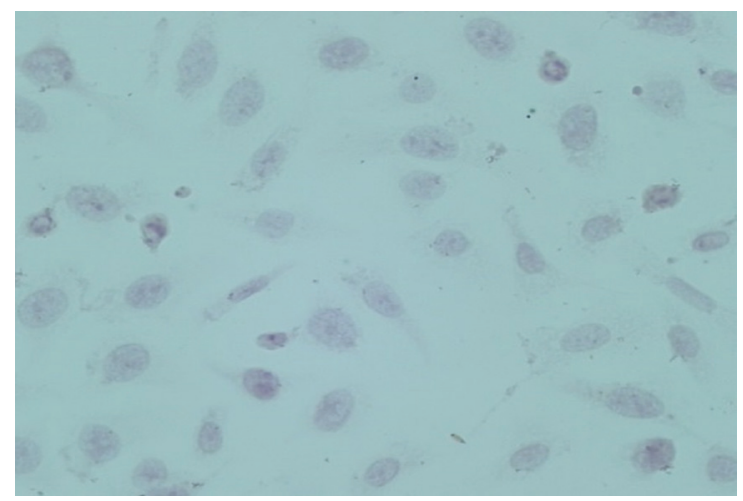

Figure 13: Expression of bcl-2 in T47D cells exposed to doxorubicin concentration of $0.1 \mu \mathrm{G} / \mathrm{mL}$

Description: Black arrows indicate cells expressing bcl-2.

cells indicated that the metformin inhibits T47D cell growth through activation of AMPK and histone $\mathrm{H} 2 \mathrm{~B}$ inhibition monoubiquitination ${ }^{[31]}$ and metformin caused apoptosis in T47D cells and increased expression of caspase 8 and 9. ${ }^{[32]}$ The study used the serial concentrations of 5,10 , and $50 \mu \mathrm{M}$ and evaluated for 24,48 , and 72 hours, the maximum effect occurred after exposure to metformin $50 \mu \mathrm{M}$ for 72 h. $^{[32]}$

Other studies on MDA-MB-231 and MDA-MB-435 cell types of breast cancer cells using serial concentration of $1.25,2.5,5,10$, and $20 \mathrm{mmol} / \mathrm{l}$ for 24,48 , and $72 \mathrm{~h}$. Cells undergoing apoptosis increased from $7 \%$ with exposure to $5 \%$ metformin to $39.6 \%$ with exposure to $20 \mathrm{mM}$ metformin for 24 hours, cytotoxic effects and apoptosis of metformin through the intrinsic mitochondria-mediated apoptosis pathway. ${ }^{[33]}$

It noted that p53 was a tumor suppressor that maintained gene stability, played a role in the cell cycle, apoptosis, senescence, and differentiation. The mutation of $\mathrm{p} 53$ will cause a loss of the function of maintaining genome stability, even triggering cancer ${ }^{[14,34,35]}$ Decreasing expression of p53 protein that undergoes mutations in T47D cells will reduce the growth of cancer cells; this is in line with the effect on the extension of the G0-G1 phase in the cell cycle; there are barriers to cell growth. P53 acts as a mediator for cell cycle arrest. ${ }^{[36]}$ This is consistent with research on T47D cells and MDAMB- 468 cells by silencing endogenous $p 53$ through lentiviral shRNA which shows massive cell death through apoptosis with nuclear blebbing, PARP-1 cleavage but does not occur in MCF-7 or MCF-10A with normal p53 conditions. ${ }^{[14]}$

It is also stated that mutant p53 is an activator of a number of genes such as c-Myc, topoisomerase $\mathrm{I}$, and MDR-1 ${ }^{[19]}$ which cause genome instability and the occurrence of spindle checkpoint control interference. ${ }^{[17]}$ This study observed three protein expressions, namely $\mathrm{p} 53, \mathrm{bcl}-2$, and cyclin D1. The results showed a decrease in expression of p53, bcl2 , and cyclin D1 proteins. Decreasing the expression of p53 in T47D cells which in a state of mutation explains the effects of metformin and doxorubicin inhibiting T47D cell growth. Lim et al. in their study stated that in cells T47D and MDA-MB-468 (both cells experienced a p53 mutation), after p53 was silenced with lentiviral shRNA, there was no change in the expression levels of pro-apoptotic proteins that were directly regulated $\mathrm{p} 53$ such as PUMA and NOXA. ${ }^{[14]}$ The connection of $\mathrm{p} 53$ with bcl 2 could be seen from the following figure, which explained that the regulation of $\mathrm{p} 53$ could occur directly by binding to bcl2 or through PUMA, NOXA, and Bim [Figure 14]..$^{[37]}$

Decreasing bcl2 expression in T47D cells exposed to metformin and doxorubicin could explain the increase in cells undergoing apoptosis in this study. It would be stated that a decrease in bcl2 expression is one of the mechanisms of apoptosis that occurred in T47D cells exposed to metformin and doxorubicin.

Replication and division of cell DNA occurs through the cell cycle, where the cell cycle was a sequence of sequences which included G1 (pre-synthesis), 


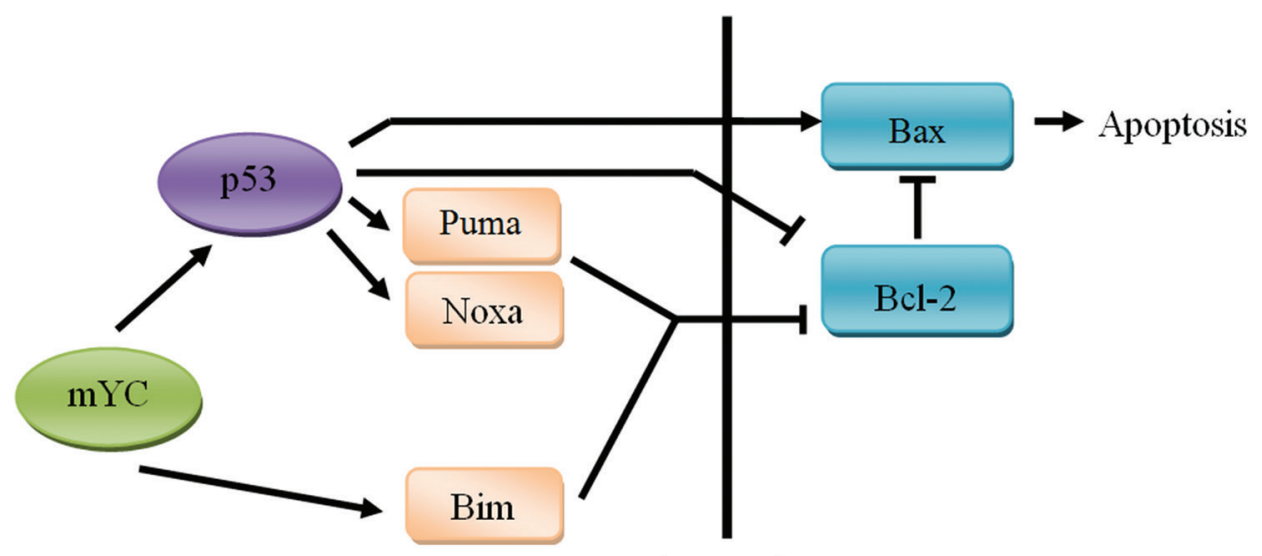

Apoptotic

Threshold

Figure 14: Connection of P53 with bcl2 ${ }^{[38]}$

$S$ (DNA synthesis), G2 (premitotic), and M (mitotic) phases. Each phase of the cell cycle will occur if the previous cell cycle is complete and will stop if there is an essential deficiency of gene function. Each phase of the cell cycle will be regulated by the cyclin and the type of cyclin that regulates differently for each phase. ${ }^{[38]}$

In the cell cycle occurs when critical in the form of checking (checkpoint) in several places including the phase G1-S and G2-M. For checkpoints in Phase G1-S are regulated by cyclin and CKI inhibitors including cyclin D1, cyclin E, p21, and p27. Overexpression of cyclin D1 and cyclin E supports the development of cancer. ${ }^{[39,40]}$ There was a decrease in the expression of D1 cyclin between control T47D cells and T47D cells exposed to metformin. Decreasing cyclin D1 expression can explain the occurrence of arrest in the phase cell cycle G0-G1 and in accordance with the study of Cai et al. on HepG2 cells. ${ }^{[12]}$

\section{Conclusions}

Conclusions of this experimental research are as follows:

1. The results of research conducted on the metformin in T47D cells; it found the effect of metformin on small cell cycle barriers, inhibits GO-G phase. Metformin has a smaller effect in stimulating T47D breast cancer cell apoptosis than that of doxorubicin.

2. Metformin was able to reduce the expression of p53, bcl-2, and cyclin D1 in T47D breast cancer cells compared to control cells.

3. As a single drug, metformin could effectively destroy breast cancer because it only makes a small quantity to halt the cancer growth. It needs to combine metformin with other drugs.

\section{Acknowledgment}

We are grateful to PT. Dexa Medica, Laboratory of Clinical Parasitology and Pathology, Faculty of Medicine, Gadjah Mada University, Indonesia.

\section{References}

1. Ferlay, J, Shin HR, Bray F, Forman D, Mathers C, Parkin DM, et al. Estimates of worldwide burden of cancer in 2008: GLOBOCAN 2008. Int J Cancer 2010;127:2893-917.

2. Tao ZQ, Shi A, Lu C, Song T, Zhang Z, Zhao J, et al. Breast cancer: Epidemiology and etiology. Cell Biochem Biophys 2015;72:333-8.

3. Moiseenko F, Volkov N, Bogdanov A, Dubina M, Moiseyenko V. Resistance mechanisms to drug therapy in breast cancer and other solid tumours: An opinion. F1000Res 2017;6:288.

4. Daugan M, Wojcicki AD, d'Hayer B, Boudy V. Metformin: An anti-diabetic drug to fight cancer. Pharmacol Res 2016;113:675-85.

5. Birsoy K, Possemato R, Lorbeer FK, Bayraktar EC, Thiru P, Yucel B, et al. Metabolic determinants of cancer cell sensitivity to glucose limitation and biguanides. Nature 2014;508:108-12.

6. Lin $\mathrm{CM}$, Huang $\mathrm{HL}$, Chu FY, Fan $\mathrm{HC}$, Chen HA, Chu DM, et al. Association between gastroenterological malignancy and diabetes mellitus and anti-diabetic therapy: A nationwide, populationbased cohort study. PLoS One 2015;10:1-11.

7. Wheaton WW, Weinberg SE, Hamanaka RB, Soberanes S, Sullivan LB1, Anso E. et al. Metformin 


\section{Rangkuti, et al.: Metformin and expression of P53, BCL2, and Cyclin D1}

inhibits mitochondrial complex $\mathrm{i}$ of cancer cells to reduce tumourigenesis. Elife 2014;2014:1-18.

8. Owen MR, Doran E, Halestrap AP. Evidence that metformin exerts its anti-diabetic effects through inhibition of complex 1 of the mitochondrial respiratory chain. Biochem J 2000;348 Pt 3:607-14.

9. Queiroz EA, Puukila S, Eichler R, Sampaio SC, Forsyth HL, Lees SJ, et al. Metformin induces apoptosis and cell cycle arrest mediated by oxidative stress, AMPK and FOXO3a in MCF-7 breast cancer cells. PLoS One 2014;9:e98207.

10. Hardie DG. AMP-activated protein kinase-an energy sensor that regulates all aspects of cell function. Genes Dev 2011;25:1-14.

11. Wibowo YC, Mahanani MR, Budiani DR, Mudigdo A. P0101 metformin inhibits cyclin D1 expression in a p53-deficient colon cancer cell line in vitro. Eur J Cancer 2015;51:e20.

12. Cai X, Hu X, Cai B, Wang Q, Li Y, Tan X, et al. Metformin suppresses hepatocellular carcinoma cell growth through induction of cell cycle G1/G0 phase arrest and p21CIP and p27KIP expression and downregulation of cyclin D1 in vitro and in vivo. Oncol Rep 2013;30:2449-57.

13. Li P, Zhao $M$, Parris $A B$, Feng $X$, Yang $X$. P53 is required for metformin-induced growth inhibition, senescence and apoptosis in breast cancer cells. Biochem Biophys Res Commun 2015;464:1267-74.

14. Lim LY, Vidnovic N, Ellisen LW, Leong CO. Mutant p53 mediates survival of breast cancer cells. $\mathrm{Br} \mathrm{J}$ Cancer 2009;101:1606-12.

15. Weinberg RA.The biology of cancer. J Neonatal Nurs 2007;13:83-6.

16. Scorrano L, Korsmeyer SJ. Mechanisms of cytochrome C release by proapoptotic BCL-2 family members. Biochem Biophys Res Commun 2003;304:437-44.

17. Matas D, Sigal A, Stambolsky $P$, Milyavsky $M$, Weisz L, Schwartz D, et al. Integrity of the N-terminal transcription domain of $\mathrm{p} 53$ is required for mutant p53 interference with drug-induced apoptosis. EMBO J 2001;20:4163-72.

18. Bergamaschi D, Gasco M, Hiller L, Sullivan A, Syed N, Trigiante G, etal. P53 polymorphisminfluences response in cancer chemotherapy via modulation of p73-dependent apoptosis. Cancer Cell 2003;3: 387-402.

19. Murphy KL, Dennis AP, Rosen JM. A gain of function p53 mutant promotes both genomic instability and cell survival in a novel p53-null mammary epithelial cell model. FASEB J 2000;14:2291-302.

20. Rangkuti IY, Hasibuan PA, Widyawati T. The Cytotoxic test of metformin hydrochloride to T47D breast cancer cell. Int J Sci Res Methodol 2018;10:1-7.

21. Hostanska K, Nisslein T, Freudenstein J, Reichling J, Saller R. Evaluation of cell death caused by triterpene glycosides and phenolic substances from Cimicifuga racemosa extract in human MCF-7 breast cancer cells. Biol Pharm Bull 2004;27:1970-5.

22. Cho HS, Chang SH, Chung YS, Shin JY, Park SJ, Lee ES, et al. Synergistic effect of ERK inhibition on tetrandrine-induced apoptosis in A549 human lung carcinoma cells. J Vet Sci 2009;10:23-8.

23. Nurse P. A long twentieth century of the cell cycle and beyond. Cell 2000;100:71-8.

24. Ruddon RW. Cancer Biology. Oxford: Oxford University Press; 2007.

25. Qu Z, Zhang Y, Liao M, Chen Y, Zhao J, Pan Y, et al. In vitro and in vivo antitumoral action of metformin on hepatocellular carcinoma. Hepatol Res 2012;42: 922-33.

26. Motoshima $\mathrm{H}$, Goldstein BJ, Igata $\mathrm{M}$, Araki E. AMPK and cell proliferation AMPK as a therapeutic target for atherosclerosis and cancer. J Physiol 2006; 574:63-71.

27. Bruton L, Lazo JS, Parker KL. Goodman and Gilman's The Pharmacological Basis of Therapeutics. New York: McGrawHill. Lange; 2005.

28. Wattanapitayakul SK, Chularojmontri L, Herunsalee A, Charuchongkolwongse S, Niumsakul S, Bauer JA, et al. Screening of antioxidants from medicinal plants for cardioprotective effect against doxorubicin toxicity. Basic Clin Pharmacol Toxicol 2005;96:80-7.

29. Barzegar E, Fouladdel S, Movahhed TK, Atashpour S, Ghahremani MH, Ostad SN, et al. Effects of berberine on proliferation, cell cycle distribution and apoptosis of human breast cancer T47D and MCF7 cell lines. Iran J Basic Med Sci 2015;18:334-42.

30. Sharma G, Tyagi AK, Singh RP, Chan DC, Agarwal R. Synergistic anti-cancer effects of grape seed extract and conventional cytotoxic agent doxorubicin against human breast carcinoma cells. Breast Cancer Res Treat 2004;85:1-2.

31. DU Y, Zheng H, Wang J, Ren Y, Li M, Gong C, et al. Metformin inhibits histone $\mathrm{H} 2 \mathrm{~B}$ monoubiquitination and downstream gene transcription in human breast cancer cells. Oncol Lett 2014;8:809-12.

32. Haji HA, Sheibak H, Khosraavi M, Asadi J. The effect of metformin on the expression of caspase 3, 8, 9 and PARP-1 in human breast cancer cell line T47D. Int J Health Stud 2016;2:147-53.

33. Gao ZY, Liu Z, Bi MH, Zhang JJ, Han ZQ, Han X, et al. Metformin induces apoptosis via a mitochondriamediated pathway in human breast cancer cells in vitro. Exp Ther Med 2016;11:1700-6.

34. Liu DP, Song H, Xu Y. A common gain of function of p53 cancer mutants in inducing genetic instability. Oncogene 2010;29:949-56.

35. Sigal A, Rotter V. Oncogenic mutations of the p53 tumor suppressor: The demons of the guardian of the genome. Cancer Res 2000;60:6788-93.

36. Kastan MB, Onyekwere O, Sidransky D, Vogelstein $B$, Craig RW. Participation of $p 53$ protein in the cellular response to DNA damage. Cancer Res 1991;51:6304-11. 
37. Hemann MT, Lowe SW. The p53-bcl-2 connection. Cell Death Differ 2006;13:1256-9.

38. Kumar V, Abas AK, Foustro N. Pathology Basic of Disease. New York: Elsevier Inc; 2005.

39. Biliran $H$ Jr. Wang $Y$, Banerjee $S, X u H$, Heng $H$, Thakur A, et al. Overexpression of cyclin D1 promotes tumor cell growth and confers resistance to cisplatin-mediated apoptosis in an elastase-myc transgene-expressing pancreatic tumor cell line. Clin Cancer Res 2005;11:6075-86.

40. Nielsen NH, Arnerlöv C, Emdin SO, Landberg G. Cyclin e overexpression, a negative prognostic factor in breast cancer with strong correlation to oestrogen receptor status. Br J Cancer 1996;74:874-80. 